\title{
COMUNICAREA ÎN SOCIETATE ȘI ÎN BISERICĂ
}

\section{Elena Mihaela JURCAN*}

\begin{abstract}
Communication in society and in Church $^{1}$. The study I have made follows a comparison between the two ways of dialogue offered by our society and the Church. We live in a society that can be called postChristian, post-individual, but primarily is post-dialogical. The man of the third millennium does not need alterity or the other, but it is sufficient for himself. This situation puts the man in a state of "socialization" but not of dialogue. Authentic Christianity insists on dialogue, showing that it is the form through which the human condition ca reach perfection. Dialogue in Christianity takes a doxological form, referring to God, helping in the same time the fulfillment of the other. By dialogue, man is fulfilled because in the Church we are talking about a charismatic and logosiatic dialogue. God by His Incarnation has shown His will to engage in dialogue with man. Through Jesus Christ people were able to see His existential Light and Goodness. So man could stand face to face with God in a communional dialogue through which he felt grace and divine peace. For this reason, the Christian is in the church never alone, but together with others people in prayer and communion, also with all creation and with God. Unfortunately, in the present society the other (my brother) is canceled, in his place we have the digital interface, which isolates and transmits information only, without any feeling or response and without communion. Only in Christ we rediscover our face and communication, through which we achieve the full communion. Through this communion we begin our eternal epektasis.
\end{abstract}

Keywords: dialogue, monologue, communication, society, church, communion.

* PhD Candidate, Faculty of Orthodox Teology at „1 Decembrie 1918” University, Alba Iulia, Romania.

${ }^{1}$ Studiu redactat sub îndrumarea Pr. Conf. Univ. Dr. Jan Nicolae, care a dat acordul pentru publicare. 


\section{Introducere}

Societatea acestui al treilea mileniu se caracterizează în primul rând prin prefixul ,post”. Avem o societate postbelică, deși prezența războiului pe mapamond este mult mai activă și foarte vizibilă. Trăim într-o epocă în care prefixul „post” se vrea a fi expresia progresismului, deși nu se ştie dacă este progres sau, mai degrabă, regres.

Societatea se vrea apoi post-industrială, deoarece se vorbește despre o nouă epocă, digitală, care depășește era industrială din secolele XIX-XX, considerată prea învechită și poluantă. Și aici avem ceva de spus, căci deși ne place să ne considerăm o eră digitală, poluarea mediului prin industrie nu numai că nu s-a micşorat, ci a depășit toate normele de încălzire globală, devenind cvasi-ireversibilă.

Vorbim despre epoca post-modernă, ceea ce arată că lumea s-ar fi modernizat; adevărul este doar parțial real, pentru că marea masă a populației lumii trăiește rudimentar și mulți nu au reuşit să plece din spațiul rural pentru a vizita zonele urbane, iar turismul, pentru cei mai multi, este doar o expresie de vocabular.

Putem vorbi despre o societate post-creștină care a reușit prin media să discrediteze atât de mult creștinismul, fără însă a oferi ceva în schimbul spiritualității evanghelice, și care, deși se autodefinește ca o societate umanistă, pierde din vedere că prima caracteristică a umanului este spiritul. Un uman fără spirit rămâne în sfera zoologiei, neputând atinge niciodată treapta antropologiei.

O ultimă caracteristică a societății mileniului al treilea, asupra căreia o să insist, este cea post-dialogală, cu alte cuvinte, societatea nu mai dialoghează, ci a reușit să creeze ființe monologale care să-și impună ideile fără a intra într-un dialog cu ceilalți, fără a căuta adevărul. Monologul omului contemporan înseamnă ruperea de celălalt, de alteritate, şi pierderea vocaţiei pentru care a fost creat: comuniunea ${ }^{2}$. Din creație, omul a fost marcat de această stare de comuniune și dialog. Primul cu care dialoga omul era Dumnezeu, apoi creaţia întreagă. Desăvârşirea omului stă în dialog. Reducerea dialogului la un egoism monologal înseamnă pierderea vocației creaționale a omului.

2 „Trăim o epocă a mutației universale - spunea Andre Chouraqui - Timpul și spațiul șiai ieșit din matcă”. Andre CHOURAQUI, Cele zece porunci ale zilelor noastre, trad. Nicoleta Neagoe, București, Edit. Humanitas, 2012, p. 207. 


\section{Comunicarea în societatea contemporană. Formele de comunicare ale acesteia}

$\mathrm{Cu}$ siguranță că nu putem vorbi de o societate non-verbală astăzi. Oamenii comunică, pentru că verbalitatea este un fenomen ființial al umanului, „este parte integrată a lui a fi în lume, a existenței noastre ca ființe aflate permanent în relație cu ceilalți, pe care îi simțim ca prezențe efective, apropiate sau îndepărtate"'3 însă formele de comunicare pe care le întâlnim astăzi sunt golite de sens constructiv (sensul de a constitui ființa umană). Niciodată ca acum informația nu a fost mai la îndemâna omului. Un simplu „clik” și aproape orice informație din colțurile lumii mai mult sau mai puțin profundă este la îndemână. Mulți au pus deja problema dacă mai este nevoie de școală sau doar de wikipedia, pentru că ultima sursă oferă mult mai mult și mai ușor informația. În plus, copilul nu mai trebuie să meargă la școală, nu mai sunt cheltuieli colaterale, totul se învață de la masa de birou, de acasă, simplu și gratuit. Deja s-a ajuns la mentalitatea de excludere a școlii prin accesarea unui învățământ prin rețeaua de internet. Astfel a apărut și în România destul de timid varianta educația de acasă, „homeschooling”. Acest sistem a devenit cunoscut și public când Dana Nălbaru și Dragoș Bucur, imagini media, și-au retras fiica de la școală și sau hotărât să o educe acasă $\breve{4}^{4}$. Acest nou sistem de educație întâlnește, după cum era de aşteptat, păreri pro și contra. El este legal și se aplică la noi doar în cazul copiilor cu dizabilități, care apelează la o ,școală umbrelă" pentru recunoașterea cunoștințelor copilului și eliberarea unei diplome recunoscute în sistemul de învățământ din România. Această formă de educație neglijează unul dintre cei mai importanți factori ai educabilității, care nu este numai informal, ci și comuniunea cu celălalt. Copilul, în comuniune cu celălalt, învață cum să se comporte, cum să se respecte și cum să dialogheze cu ceilalți. Învățământul în comuniune este și mimetic, copiii imitând gesturile dascălului.

${ }^{3}$ Ioan SCHEAU, Ioan LEVIȚCHI, Comunicarea-monografia unui concept, Alba Iulia, Edit. Reîntregirea, 2007, p. 86.

${ }^{4}$ Conform datelor Asociației Scooling România (organizație înființată în anul 2002), circa 200 de familii pe an hotărăsc să-și educe copiii în acest sistem. Cei care au o mai mare deschidere sunt românii din București și Transilvania, pe când în celelalte zone ale țării părinții sunt mai reticenți. https://revistacariere.ro/inovatie/trend/homeschooling-in-romania-solutie-reala-sauextravaganta-de-moment (accesat la data de 20.06.2019). 
Încercarea de a readuce omul în individualismul lui păgubos o regăsim și în învățământ, dar și mai departe. În individualismul lui „homo faber”, mai ales în domeniul IT, pentru o reducere a cheltuielilor cu chiria și întreținerea spațiului, se merge pe ideea că omul poate lucra de acasă, importantă fiind conexiunea la internet. Izolarea lui în această formă de ,pseudo-isihie-tehnică” nu face altceva decât să-l transforme într-un robot lipsit de sentimentul comuniunii cu colegii și de comunicarea cu aceștia atât în plan profesional, cât și afectiv și spiritual. Oamenii sunt preocupați în totalitate de munca lor, astfel încât nu le mai rămâne timp să gândească şi să-și exprime celuilalt conținutul gândurilor ${ }^{5}$. Putem vorbi apoi de apariția lui „homo connecticus” și „homo communicans”, urmare a apariției noilor media. „Conexiunea și comunicarea mediatică au devenit o a doua natură, încât pentru mulți dintre contemporanii noștri este de neimaginat o existență lipsită de ele. A trăi fără televizor, fără calculator, fără tabletă, fără smartphone, pentru

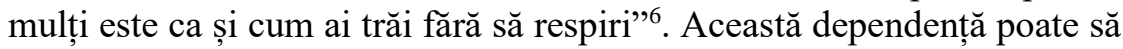
fie percepută ca o permanentă nevoie de comunicare, o comunicare glaciară, depersonalizată, individualistă, de căutare a senzaționalului și a noului.

$\mathrm{O}$ altă dimensiune a comunicării în mileniul al treilea este forma non-verbalității. Altfel spus, deși ştim că omul este un logos, comunicarea a devenit mai degrabă o expunere de semne decât un dialog. Probabil, această nevoie de comunicare non-verbală a dus la apariția emoticoanelor și literele cu caracter de cuvânt (k-ca, cmf-ce mai faci, bn-bine etc.). Urmează apoi o amalgamare de semne și sensuri, în care limba maternă este impregnată de termeni străini, ceea ce astăzi numim ,romgleza”. O astfel de limbă nu mai are sentiment, este o simplă pseudo-informație a unei societăți care se vrea a fi foarte confortabilă și comodă. Dimensiunea acestei societăți este vastă şi singurul termen care o poate defini este prefixul „post”. Putem vorbi despre o post-verbalitate umană, în care cuvântul este înlocuit de tastă, iar limba de degetele mâinii și touchscreen. Într-o astfel de societate greu se mai poate vorbi de comunicare, iar eufemicul „socializare”

${ }^{5}$ Teofan MADA, Eu și Tu. Relația ca întâlnire prezentă și comunicarea iubitoare, ClujNapoca, Edit. Vremi, 2010, p. 154.

${ }^{6}$ Jean-Claude LARChET, Captivi în internet, trad. Marinela Bojin, București, Edit. Sofia, 2016, p. 115. 
ascunde dureroasa expresie de comunicare non-dialogală și nonprosoponică.

Această comunicare are mai multe tipuri de manifestări. Există chiar o presiune digitală asupra dependentului de media, care poate fi numită chiar „o spălare de creier”. Cât de ușor se poate face astăzi o manifestație printr-o simplă convocare de la birou a blogărilor „specialiști” în a orienta unidimensional adepții aceleiași rețele. Am putea spune că liderii ar putea fi anonimi, dacă rețeaua de socializare este bine gândită. Oamenii nu mai au nevoie de personalități cu carismă, uneori nici de majorități politice și nici chiar de războaie, ci cel mult de agasarea multi-media prin mesaje care, de cele mai multe ori, sunt fakenews-uri. Să ne amintim de demonstrațiile din Piața Victoriei din București sau de numitele Jachete Galbene de la Paris. Nimeni nu cunoaște liderii, dar toată lumea s-a supus obedient ordinelor anonime, venite pe rețea, pentru a participa la demonstrații și proteste. Inclusiv sloganele erau transmise online pe telefoane, fără ca cineva să mai aibă timp să vadă dacă erau adevărate sau nu. Aceasta este una dintre caracteristicile societății ,„post”.

Pe această linie multi-media a fake news-ului publicitar sunt transmise informații prea puțin veridice despre medicamente, produse alimentare, suplimente nutritive, diete etc. Prin acest tip de comunicare lumea este condusă informațional persuasiv de către grupuri anonime bine pregătite în manipularea multi-media. Tipul acesta de comunicare poate să fie foarte distructiv. S-a ajuns până la a se distruge personalitatea umană prin cavalcada de informații împotriva unui om care sub această presiune a clacat, ajungând la sinucidere, iar cazurile nu sunt puține. Presiunea multimedia poate dezechilibra omul și chiar o face.

Comunicarea post-dialogală și post-religioasă în mileniul al treilea afectează enorm educația tinerilor. Dependența de multi-media a dus la apariţia unor boli necunoscute acum cincizeci de ani, cum ar fi: ,autismul cibernetic”, prin care, medical vorbind, creierul nu se dezvoltă proporțional. Tot legat de această presiune multimedia asupra organismului uman poate fi și apariția stresului ca boală generală a comunității umane, cu toate consecințele ei. Stresul devine prima cauză a tuturor tulburărilor din constituţia umană, anatomo-psihologică. Naşterea copiilor cu noua boală ADHD este urmarea unui stres 
comunicativ asupra universului emoţional al mamei și asupra fătului (mama transmite starea de nervozitate și agitație copilului).

Lipsa comunicării verbale în această societate monologal-multimediatică are repercusiuni și asupra familiei care nu-și mai găsește răstimpul de a-și transmite gândurile și sentimentele. Membrii familiei nu mai comunică între ei, toți au telefoane performante, care le ocupă majoritatea timpului, izolându-i într-o lume virtuală, într-o altfel de familie, care nu face altceva decât să-i rupă de comuniunea familială şi să le ofere un confort sentimental. Criza familiei, rata divorțurilor și promovarea cuplului în locul cununiei sunt consecința acestei comunicări deficitare. Dispare rușinea, pudoarea, intimitatea, iar în locul lor apare ușurința de a face publică viața privată cu toate aspectele ei, cu deschiderea de-a putea interveni și comenta, nu pentru îndrumare, ci pentru a te face auzit și vizibil. Așa a apărut blogul, un fel de jurnal personal, public, care oferă informații și imagini zilnice din viața privată cu permisiunea vizitatorilor de a scrie comentarii la evenimentele care se desfășoară, fără nici un fel de cenzură.

Monologarea informațională a făcut să dispară încet-încet din preocuparea omului lectura; lectura dintr-o carte cu miros de hârtie și vopsea tipografică. Au apărut Ebook-uri care nu mai au acelaşi efect euristic asupra cititorului. Lectura dezvoltă limbajul, limbajul devine dialog și comuniune, iar comuniunea duce la desăvârșire.

\section{Un răspuns ortodox. Comunicarea prin prisma Bisericii}

Comunicarea din prisma Bisericii și a teologiei înseamnă, de fapt, definirea ființei umane în relaţie cu celălalt. Omul nu este deplin decât în relație și comuniune cu celălalt. „Celălalt” este, pe de-o parte, Dumnezeu, pe de altă parte, creația-omul. Fără starea dialogală, omul este incomplet ființial, pentru că prin Logos și comunicare omul se dăruiește. A fi creat după chipul lui Dumnezu nu înseamnă numai rațiune, sentiment şi voință, aşa cum se învață în manualele de doctrină scolastică, ci înseamnă, pe de-o parte, a fi ființă liberă, a fi creație dialogală și, pe de altă parte, a fi existență dăruitoare. Mai concret, omul creat după chipul lui Dumnezeu se dăruiește prin cuvânt celuilalt, creând comuniunea, aşa cum aceasta exista în Rai între om şi Dumnezeu, pentru că „originea și sensul comunicării își au izvorul lor 
veșnic în comuniunea de viață treimică"’7. Omul în Rai nu vorbește cu Dumnezeu decât într-un mod euharistic, de dăruire; când omul cade, euharistia Logosului lui Dumnezeu se pierde, iar omului îi lipsește puterea hrănitoare a logosului. Omul în Rai posedă starea dialogală care este constitutivă pentru ființa umană. În vorbirea lui cu Dumnezeu, omul se întărea în propria lui existență. Așadar, nu vorbim de un dialog ca verbalitate, poli-loghie, ci de o hrănire logosiatică în Rai a omului. Această hrană a logosului crea comuniunea între om și om (Adam și Eva, între ei şi creație). Forța logosiatică a omului era atât de puternică în comuniunea cu Dumnezeu, încât Dumnezeu îl desemnează pe om să pună nume animalelor. Prin aceasta omul nu este un simplu botanist sau ornitolog, pentru că numele desemnat de om înseamnă fiinţialitatea fiecărei creaturi în parte, iar acestea îl recunosc pe om. Când omul cade, creația nu-1 mai recunoaște ca stăpân, pentru că omul nu mai are forța harică de a o domina și de a o conduce.

Așadar, cea mai puternică legătură dialogală a fost pentru om în Rai, unde comunicarea cu Dumnezeu crea acea stare de profunzime epectatică prin care omul urca în desăvârşire. Pe de altă parte, omul paradisiac crea comuniunea într-o stare de jertfă, cu alte cuvinte, elementele euharistice existau într-o stare de germinaţie de atunci: omul se dăruia, se jertfea prin cuvânt. Dialogul însemna a da ceva din tine celuilalt, într-o stare de har. După cădere, omul devine egoist: cuvântul nu mai are putere de comuniune și, cu atât mai puțin, de consolidare ființială. Cuvântul devine ipocrit, fățarnic, iar primul cuvânt după cădere este minciuna.

Abia prin Hristos, cuvântul este reconstituit ca formă, prin comuniune şi prin refacerea comunităţii cu adevărat harice. Hristos aduce starea de ,har peste har”, care dă omului forța de a redeveni ce a fost. „Aceasta întrece limitele imaginaţiei și îndrăznelii umane, este taina iubirii mai presus de lume ascunsă de la început în Dumnezeu" (Efes. 3, 9). Harul exista și în Vechiul Testament, însă avea o acțiune destul de restrânsă: de a păstra providența creației și de a transmite revelația autentică. Prin Hristos se ajunge la starea de har peste har, în care nu doar lumea nu se mai întoarce în neant, dar și adevărul revelat rămâne stabil și omul poate redeveni syndesmosul (inelul de legătură al)

${ }^{7}$ Nicolae DASCĂLU, Comunicare pentru comuniune, Iași, Edit. Trinitas, 2000, p. 13. 
creației. Zicala: „omul sfințește locul” din înțelepciunea populară românească devine reală din punct de vedere teologic, pentru că omul sfânt resacralizează toposul sau locul creației.

În primul rând, Hristos aduce în istorie realitatea comuniunii prin dialog, adică omul descoperă alteritatea dialogală, iar comunicarea devine revărsare de har ca în starea paradisiacă. Omul poate comunica cu celălalt în Hristos pentru că el se cuminecă din celălalt și, în același timp, își dăruiește euharistic viața pentru celălalt. Aceasta este starea de sfințenie după modelul Mântuitorului. Primul lucru pe care îl face Hristos când iese în fața lumii la treizeci de ani este să propovăduiască, să comunice cu omul și creația. El transmite adevăruri revelate într-o formă dialogală, după capacitatea de percepere a omului. El nu dă umanităţii mai mult decât poate duce. De aceea le spune ucenicilor: „Încă multe am a vă spune, dar acum nu puteți să le purtați” (In. 16, 12). Prima cerință a Lui față de Apostoli este: „Mergând, învățaţi toate neamurile" (Mt. 28, 19), adică să le transmită starea paradisiacă, astfel încât, prin conștientizare, oamenii apoi să-și dorească botezul. Părintele și Sfântul Iustin Popovici vorbește despre sensul creației prin Logosul lui Dumnezeu. El vede viața, în lucrarea sa Omul și Dumnezeu Omul, ca pe o permanentă luptă cu moartea, iar salvarea ei stă doar în Învierea lui Hristos $^{8}$.

Biserica a preluat mesajul lui Hristos și a continuat starea de dialog, eliminând orice formă monologală în comuniune și comunicare cu alteritatea, omul îndeplinindu-și astfel menirea. Biserica nu este o instituție, ci mai degrabă starea de trăire în Hristos, care depășește orice formă oficială $\breve{9}^{9}$. În ea, omul devine persoană și nu individ. De aceea Părinții Bisericii au refuzat de la început definirea omului ca individ sau ființă monologală. Omul este prosopon, adică față; față-către-faţă. O față nu poate să fie față decât dacă este văzută de altă față, iar față-n față înseamnă dialog și nu monolog. Toate angoasele umanității dispar prin dialog haric. Cea mai puternică comuniune ar fi putut să se realizeze în

${ }^{8}$ Iustin PoPOvici, Omul și Dumnezeul Om. Abisurile și culmile filosofiei, trad. Ioan Ică sr. și Ioan I. Ică jr., Sibiu, Edit. Deisis, 1997, p. 43.

9 „Biserica este întruparea persoanei Dumnezeu-omului Hristos, un organism divinouman şi nu o organizaţie omenească", zice același Iustin PoPOVICI, în lucrarea sa: Credința Ortodoxă și viața în Hristos, trad. Paul Bălan, Galați, Edit. Bunavestire, 2003, p. 13. 
istorie numai în Biserică, iar nucleul ei să fie Hristos din sinaxa Liturghiei. Biserica creștină oferă comuniunea printr-o singură limbă: „limba Duhului Sfânt”. Adevărata menire a Bisericii era nu cea de a deveni o instituție etnocentrică, adică devenind o singură etnie și o singură limbă, ci ea trebuie să fie supraetnică, creând comuniunea și comunitatea prin limba Duhului Sfânt, care înseamnă revelație și adevăr în numele Sfintei Treimi. Din păcate, în decursul istoriei, Biserica cea una a lui Hristos s-a dezmembrat, confesionalizându-se în diferite fracțiuni în care orgoliul uman a devenit prioritar faţă de revelaţia divină. De aceea, în istoria Bisericii am asistat cu părere de rău la atâtea conflicte (multe militare) soldate cu condamnări, anatematizări, expulzări și chiar masacrări în numele Celui care a venit și a spus aşa de simplu: „Pace vouă!” (In. 20, 21). Nu am înţeles din istorie că pacea lui Hristos înseamnă o pace dialogală, harică, care creează comuniune în pregătirea euharistică.

Ceea ce ne oferă societatea post-religioasă este un fals existenţial; omul trăiește iluzia unei fericiri individuale, uitând că adevărata fericire este cea care se dăruiește. Promovarea individualismului, construit cu toată reclama mediatică, nu face decât să-l rupă pe om de propria vocaţie divină: aceea de a fi portavocea dialogului, partener de dialogcomuniune cu Dumnezeu și creația. Tocmai pentru că Biserica cheamă în misiunea sa la dialog și comuniune, la comunicarea autentică, societatea individului mileniului al treilea recurge la orice mijloc de a profana Biserica și misiunea ei. Totul este orientat anti-Biserică și anticomuniune. Comunicarea nu există, pentru că omul mileniului al treilea nu mai are față-prosopon. Este cel mult un chip șters, fals, în spatele așa-zisei „socializări” multi-media. El nu mai are puterea și nici curajul de a sta față către față, așa cum a fost creat de Dumnezeu. Ascuns în spatele ecranului impersonalist, anonimul uman, care şi-a pierdut şi numele și fața, „socializează”, adică își transmite imaginea falsă a propriei fericiri (prin afișarea de fakes, poze comerciale, imagini contrafăcute) alături de perversele pofte distrugătoare existențial.

Societatea post-religioasă nu are nevoie de fețe, pentru că fața înseamnă dialog, iar dialogul înseamnă cunoaștere și cunoașterea duce la verticalitatea umană nemanipulabilă. Un om vertical nu mai poate fi manipulat nici politic, nici economic, nici hedonist. Biserica acest lucru și-1 propune în numele lui Hristos: să verticalizeze omul prin cultura 
harică a dialogului și prin comuniunea euharistică. Prin Logos și Euharistie, în cadrul Bisericii se realizează cele două dimensiuni existențiale ale umanității: comunicarea și comuniunea. Omul redevine astfel paradisiac așa cum fusese de la început. Aceasta era adevărata lui vocație existențială. În comunicarea-comuniune, omul se restructurează hristic și ia chipul veșniciei, iar chipul lui se transmite creației întregi. Se începe procesul eshatologic de „cer nou și pământ nou”, de restaurare a creației prin sfințenia umană comunional-dialogal-harică.

Readucerea umanității la dialogul haric şi, de aici, la comuniunea cu alteritatea creațională, este scopul Bisericii în Hristos. Spaţiul hristic este infinit mai generos decât egoismul societății post-umane, postreligioase și post-morale. Europa monologală trăiește din păcate un permanent arianism, care dintru începuturi a încercat să ne prezinte un Hristos golit de divinitatate. Pentru a fi măguliți, ni se spune că Hristos a fost un mare om religios, un mare lider spiritual, o excepție a umanității. Prea puțin. El este Dumnezeu-Omul, Cel Care cheamă lumea spre acea unire cu cerul prin El. Abia prin divino-umanitatea Lui noi am primit sensul creației. Fără de El totul era o decepție, viața era un marș spre moarte, timpul și spațiu erau o permanentă devorare a ființei umane. Prin El am primit sensul eternității, iar viața noastră are un drum clar.

\section{Concluzie}

În concluzie, o astfel de societate monologală și egoistă, bazată doar pe senzualism efemer, hedonism și consumism, nu duce la împlinirea umanității și a creației, ci dimpotrivă, la distrugerea existenței umane prin oferirea de simulacre false, mascate sub termeni pompoşi: toleranță, corectitudine politică, socializare, multi-media etc. Așadar, doar într-o societate bazată pe comuniune inter-umană și divino-umană şi pe dialog haric epectatic, hrănită din seva euharistică, se poate reface o umanitate decăzută, marcată de iluzia unei soteriologii efemere.

\section{Referinţe bibliografice:}

1. ChOURAQui, Andre Cele zece porunci ale zilelor noastre, trad. Nicoleta Neagoe, București, Edit. Humanitas, 2012;

2. DASCĂLU, Nicolae, Comunicare pentru comuniune, Iași, Edit. Trinitas, 2000; 
3. LARCHET, Jean-Claude, Captivi în internet, trad. Marinela Bojin, București, Edit. Sofia, 2016;

4. MADA, Teofan, Eu și Tu. Relația ca întâlnire prezentă și comunicarea iubitoare, Cluj-Napoca, Edit. Vremi, 2010;

5. PopovicI, Iustin, Credința Ortodoxă și viața în Hristos, trad. Paul Bălan, Galați, Edit. Bunavestire, 2003;

6. PopovicI, Iustin, Omul și Dumnezeul Om. Abisurile și culmile filosofiei, trad. Ioan Ică sr. și Ioan I. Ică jr., Sibiu, Edit. Deisis, 1997;

7. SCHEAU, Ioan, LEVIȚCHI, Ioan, Comunicarea-monografia unui concept, Alba Iulia, Edit. Reîntregirea, 2007;

8. https://revistacariere.ro/inovatie/trend/homeschooling-in-romaniasolutie-reala-sau-extravaganta-de-moment (accesat la data de 20.06.2019). 